\title{
POLA KOMUNIKASI LPM SUAKA UIN SUNAN GUNUNG DJATI BANDUNG DALAM MENYELESAIKAN KONFLIK PADA KEGIATAN JURNALISTIK (Studi Kasus Lembaga Pers Mahasiswa Suaka UIN Sunan Gunung Djati Bandung)
}

\author{
Oleh: Muhammad Abassi Ali Bilhadj dan Reni Nuraeni
}

Prodi S1 Ilmu Komunikasi, Fakultas Komunikasi dan Bisnis, Universitas Telkom E-mail:muhammadbilhadj@gmail.com,reznns@yahoo.com

\begin{abstract}
ABSTRAK
Penelitian ini dilakukan untuk mengetahui pola komunikasi penyelesaian konflik pada kegiatan jurnalistik yang dilakuakan Lembaga Pers Mahasiswa Suaka UIN Suanan Gunung Djati Bandung. Tujuan dilakukannya penelitian ini adalah untuk mengetahui dan menganalisis bagaimana pola komunikasi penyelesaian konflik serta tahapan yang dilakukan untuk mengatasi konflik berkepanjangan terhadap kegiatan jurnalistik yang terjadi.

Penelitian ini menggunakan metode kualitatif, untuk memenuhi tujuan penelitian penelitian, peneliti menggunakan paradigma kritis, dengan menggunakan analisis pola komunikasi organiasi dan manajemen konflik organisasi.

Hasil penelitian menunjukkan komunikasi organisasi harus dilakukan dengan menerapkan komunikasi internal dan pola komunikasi eksternal, penerapan komunikasi internal terdiri dari pola komunikasi vertikal, pola komunikasi horizontal, dan pola komunikasi diagonal, sedangkan komunikasi eksternal dibangun menggunakan pola komunikasi dari organisasi ke khalayak dan pola komunikasi dari khalayak ke organisasi.

Komunikasi internal organisasi dibentuk lewat pola komunikasi vertikal, diterapkan pada komunikasi antara atasan dengan bawahan. Pola komunikasi horizontal, yang diterapkan pada komunikasi antar bawahan atau anggota, dan pola komunikasi diagonal, yang diterapkan pada komunikasi antara kepala divisi dengan bawahan di luar divisi yang di bawahi. Pada komunikasi eksternal dibentuk lewat pola komunikasi dari organisasi ke khalayak, komunikasi yang dilakuakan organisasi untuk menjalin hubungan atau memecahkan masalah dengan organisasi eksternal. Pola komunikasi dari khalayak ke organisasi, komunikasi yang dilakuakan sebagai respon dari kegiatan yang dilakukan organisasi, yang direspon oleh organisasi eksternal atau khalayak. Pola untuk memecahkan konflik yang terjadi yaitu menggunakan beberapa tahapan menajemen konflik organisasi, yaitu tahap pengenalan, tahap diagnosis, tahap menyepakati suatu solusi, tahap pelaksanaan dan ditutup dengan langkah evaluasi.
\end{abstract}

Kata Kunci: Pola Komunikasi, manajemen konfik organisasi, jurnalistik, lembaga pers mahasiswa.

\section{ABSTRACT}

This research was conducted to find out the communication pattern of conflict resolution in journalistic activity that was done by UIN Suanan Mahasiswa Gunung Djati Bandung UIN Suanan asylum. The purpose of this research is to know and analyze how the communication patterns of conflict resolution and the steps taken to resolve the prolonged conflict of journalistic activities that occurred. 
This research uses qualitative method, to fulfill the purpose of research research, researcher use critical paradigm, by using pattern analysis of organizational communication and organizational conflict management.

The results show that organizational communication must be done by applying internal communication and external communication pattern, the application of internal communication consists of vertical communication pattern, horizontal communication pattern, and diagonal communication pattern, while external communication is built using communication pattern from organization to audience and communication pattern from audience to the organization.

Internal communication organization is formed through a vertical communication pattern, applied to communication between superiors with subordinates. The horizontal communication pattern, which is applied to the communication between subordinates or members, and the diagonal communication pattern, applied to communication between the division head and subordinates outside the underlined division. In external communication is formed through the pattern of communication from the organization to the audience, communication that dilakuakan organization to establish relationships or solve problems with external organizations. The pattern of communication from audiences to the organization, communications that dilakuakan as a response from activities undertaken organization, which responded by external organizations or audiences. Patterns to resolve conflicts that occur are using several stages of organizational conflict management, namely the stage of recognition, the stage of diagnosis, the stage of agreeing a solution, the implementation stage and closed with evaluation steps.

Keywords: Communication Pattern, organization conflict management, journalism, student press agency.

\section{A. Pendahuluan}

Demokrasi memberikan kebebasan untuk bersuara dan berpendapat kepada setiap warga negara, lembaga pers dibentuk secara independen sebagai kontrol sosial mengenai kebijakan pemerintah dan aspirasi masyarakat. Mahasiswa merupakan kelompok yang sering mengutarakan pendapat untuk menuntut sebuah keadilan, oleh karena itu pers mahasiswa dianggap sebagai lembaga pers paling ideal karena tidak berorientasi pada kepentingan ekonomi melainkan pada idealisme mahasiswa. Pers mahasiswa adalah penerbitan yang dikelola dan diterbitkan oleh mahasiswa dengan dicirikan oleh idealisme kemahasiswaan (Wisnu, 2013: 5). Selain itu menurut Subaharianto (dalam Abrar, 1992:7), pers mahasiswa adalah penerbitan di kampus yang pengelolaannya murni dilakukan oleh mahasiswa, aktivitas keredaksian sampai dengan pencarian dana dilakukan oleh mahasiswa yang masih aktif di kampus.

Dari penelitian yang dilakuakan Perhimpunan Pers Mahasiswa (PPMI) pusat, jumlah lembaga pers mahasiswa yang terkumpul sampai tahun 2016, sebanyak 252. Jumlah lembaga pers mahasiswa terbanyak berada di Provinsi Jawa Tengah dengan jumlah 71, kemudian di urutan ke dua yaitu Provinsi Jawa Timur dengan jumlah 68, dan selanjutnya Provinsi Jawa Barat dan DIY dengan jumlah 33.

Dari jumlah lembaga pers mahasiswa yang ada di Indonesia, permasalahan mengenai kekerasan terhadap lembaga pers mahasiswa tertinggi ada di Provinsi Jawa Barat, yang terjadi di Institut Seni Budaya Indonesia Bandung (ISBI) sebanyak satu kali, dan UIN Sunan Gunung Djati Bandung sebanyak empat kali, dalam kurun waktu dari tahun 2013 sampai tahun 2016. (Hasil wawancara dengan Sekretaris Jendral Forum Komunikasi Pers Mahasiswa Bandung (FKPMB), Hasbi Ilman, Tanggal 13 November 2016), dan mengenai 
Diterbitkan oleh Program Studi IImu Komunikasi

Universitas Ahmad Dahlan Yogyakarta

permasalahan kekerasan terhadap lembaga pers mahasiswa di Provinsi lain, terjadi di Provinsi Jawa Tengah sebanyak satu kali yaitu di Universitas Kristen Satya Wacana Salatiga (UKSW), Provinsi Jawa Timur sebanyak satu kali di Universitas Jember (UNEJ), selanjutnya di Provinsi DIY terjadi di Universitas Negeri Yogyakarta (UNY) sebanyak satu kali, Universitas Sarjanawiyata Tamansiswa (UST) sebanyak satu kali dan terjadi di Universitas Ahmad Dahlan (UAD) sebanyak satu kali. (Hasil wawancara dengan Sekretaris Jendral Perhimpunan Pers Mahasiswa Indonesia (PPMI), Abdus Somad, Tanggal 9 Desember 2016). Data hasil wawancara di atas menunjukkan kekerasan terhadap lembaga pers mahasiswa, tertinggi berada di Provinsi Jawa Barat dengan jumlah kasus sebanyak 6 kali.

Masih adanya diskriminasi yang terjadi dalam pelaksanaan kebebasan pers, lembaga pers mahasiswa yang mempunyai prinsip dan tujuan sama dengan lembaga pers pada umumnya, tidak mendapatkan keadilan mengenai hukum yang memayunginya. Diskriminasi ini sering dialami oleh pers mahasiswa, pers mahasiswa tidak mempunyai payung hukum yang dapat melindungi kebebasan untuk bersuara dan tetap independen dalam menyebarkan berita sesuai dengan fakta yang ada, ancaman dan tindak kekerasan masih dialami oleh pers mahasiswa, hal ini dibuktikan dengan hasil penelitian dan data dari PPMI (Perhimpunan Pers Mahasiswa Indonesia) nasional, dimana data yang masuk dari 64 lembaga pers mahasiswa yang tersebar di Indonesia, terdapat 12 kasus tindak kekerasan yang dialami lembaga pers mahasiswa berupa pembredelan, dan sisanya 33 kasus berupa intimidasi, 5 kasus kriminalisasi, 6 kasus pelecehan, 5 kasus pembekuan.

Lembaga pers mahasiswa SUAKA UIN Sunan Gunung Djati Bandung, bermula sejak berdirinya perkumpulan mahasiswa yang bernama Gerak pada tahun 1986, produk dari Gerak sendiri menghasikan buletin kampus yang terbit setiap seminggu sekali, berisikan tentang pemberitaan kampus. Gerak berganti nama menjadi SKM Suaka, pada tahun 1991 SKM Suaka bertransformasi menjadi menjadi Suara Kampus (SUAKA), dan pada akhirnya pada tahun 2001 berubah nama menjadi lembaga pers mahasiswa SUAKA UIN Sunan Gunung Djati Bandung.

Menurut data yang didapat peneliti di lapangan, lembaga pers mahasiswa Suaka UIN Sunan Gunung Djati Bandung. Dalam kurun waktu 3 tahun terakhir, Suaka mengalami 5 kali masalah yang besar mengenai kegiatan jurnalistik, dari masalah tersebut lembaga pers mahasiswa Suaka UIN Sunan Gunung Djati Bandung sempat akan di bekukan. (Hasil wawancara dengan Ketua Lembaga Pers Mahasiswa Suaka UIN Sunan Gunung Djati Bandung Periode 2016, Robby Darmawan, Tanggal 19 Oktober 2016).

Kasus kekerasan dan konflik pada lembaga pers mahasiswa Suaka UIN Sunan Gunung Djati Bandung terjadi dengan beberapa pihak yang berbeda seperti data tabel di atas, pemecahan masalah konflik yang terjadi memakan waktu sangat lama dan memerlukan proses yang sangat panjang, karena konflik ini dilatarbelakangi oleh perbedaan presepsi serta adanya komunikasi yang tidak bagus antara kedua belah pihak. Dari semua kasus kekerasan dan konflik yang ada di lembaga pers mahasiswa Suaka UIN Sunan Gunung Djati Bandung, pihak yang berselisih dan menyerang dikarenakan kelompok atau individu tersebut merasa disoroti, dan merasa diserang oleh lembaga pers mahasiswa Suaka UIN Sunan Gunung Djati Bandung. Akan tetapi pihak yang merasa tersoroti tidak melakukan komunikasi yang baik terhadap lembaga pers mahasiswa Suaka UIN Sunan Gunung Djati Bandung, mereka secara langsung melakukan tindakan kekerasan yang dapat memicu 
konflik tersebut. (Hasil wawancara dengan Pemimpin Umum (PU) Lembaga Pers Mahasiswa Suaka UIN Sunan Gunung Djati Bandung, Isthiqonita, Tanggal 6 Februari 2017).

Banyaknya kasus kekerasan dan konflik terhadap lembaga pers mahasiswa, berdampak besar terhadap lembaga pers mahasiswa yaitu lembaga pers mahasiswa tidak dapat berperan aktif menjalankan tujuan dan tugasnya sebagai kontrol sosial bagi lingkungan kampusnya, pers mahasiswa mahasiswa seakan-akan takut untuk mengungkap fakta dan realita di lapangan untuk diberitakan, serta membuat lembaga pers mahasiswa tidak bisa mempertahankan identitas independennya. Untuk menangulangi permasalahan seperti ini dan mengembalikan fungsi serta tujuan pers mahasiswa sebagaimana mestinya, pola kumunikasi, serta komunikasi yang efektif untuk memecahkan masalah dan konflik pada lembaga pers mahasiswa harus disusun secara bagus dan terstruktur, serta penerapan kode etik jurnalistik yang tepat.

\section{B. Kerangka Teori}

\section{Komunikasi}

Komunikasi merupakan aktivitas yang dilakukan setiap harinya oleh manusia. Berkomunikasi dengan sesama manusia dapat menjalin hubungan diantara satu dengan lainnya dalam kehidupan sehari-hari. Tidak ada manusia yang tidak terlibat dalam komunikasi. Menurut Louis Forsdale (dalam Muhammad, 2009: 2), komunikasi adalah proses individu mengirim stimulus yang biasanya dalam bentuk verbal untuk mengubah tingkah laku orang lain.

Menurut William J. Seller (dalam Muhammad, 2009: 4), komunikasi adalah proses dengan mana simbol verbal dan nonverbal dikirimkan, diterima, dan diberi arti. Komunikasi juga dapat dikatakan sebagai proses pertukaran pesan verbal maupun nonverbal antara si pengirim dengan si penerima pesan untuk mengubah tingkah laku (Muhammad, 2009: 4-5).

\section{Pola Komunikasi}

Pola komunikasi adalah bagaimana kebiasaan dari suatu kelompok untuk berinteraksi, bertukar informasi, pikiran dan pengetahuan. Pola komunikasi juga dapat dikatakan sebagai cara seseorang atau kelompok berinteraksi dengan menggunakan simbolsimbol yang telah disepakati sebelumnya (Faulos, 2002: 171). Menurut Djamarah (dalam Djamarah, 2004: 1), pola komunikasi merupakan bentuk hubungan dua orang atau lebih dalam proses pengiriman pesan dan penerimaan pesan dengan cara yang tepat sehingga pesan yang dimaksud dapat dipahami dan dimengerti. Sehingga secara sederhana, dapat dikatakan bahwa komunikasi merupakan proses menyamakan persepsi, pikiran, dan rasa antara komunikator dengan komunikan (Mulyana, 2001: 7).

Pola komunikasi adalah bentuk komunikasi yang digunakan. Dalam suatu organisasi para anggota pasti saling bertukar pesan dengan anggota lainnya. Pertukaran pesan tersebut terjadi dengan melalui suatu jalan yang dinamakan pola aliran informasi atau jaringan komunikasi. (Masmuh, 2008: 56). Terdapat beberapa bentuk pola kamunikasi yang akan dijelaskan sebagai berikut: 
Diterbitkan oleh Program Studi IImu Komunikasi

Universitas Ahmad Dahlan Yogyakarta

a. Komunikasi internal menurut Lawrence D.Brennan (dalam Ruliana, 2014: 94), Komunikasi internal adalah pertukaran gagasan di antara para administrator dan anggota dalam suatu perusahaan atau organisasi guna terwujudnya tujuan perusahaan dengan struktur yang khas (organisasi) dan pertukaran gagasan itu berlangsung secara horizontal dan vertikal di dalam perusahaan yang menyebabkan pekerjaan (operasi dan manajemen) berlangsung. Komunkasi internal dalam sebuah organisasi itu ditunjang dalam beberapa bentuk komunikasi antara lain, yaitu:

- Pola Komunikasi Vertikal: Pola komunikasi vertikal adalah komunikasi yang berlangsung dari atas ke bawah (downward communication) dan dari bawah ke atas (upward communication) atau komunikasi dari pimpinan ke bawahan dan dari bawahan ke pimpinan secara timbal balik (two way traffic communication).

- Pola Komunikasi Horizontal: Pola komunikasi horizontal adalah tindakan komunikasi yang berlangsung di antara para bawahan atau bagian yang memiliki kedudukan yang setara.

- Pola Komunikasi: Pola komunikasi diagonal lintas-saluran (cross communication) adalah komunikasi antara pimpinan seksi dengan bawahan seksi lain.

b. Komunikasi eksternal adalah semua cara yang dilakukan oleh organisasi untuk berkomunikasi dengan khalayak yang dijadikan sasaran organisasi. Komunikasi eksternal dapat meliputi baik komunikasi dari organisasi ke khalayak maupun dari khalayak ke organisasi, berikut dua bentuk komunikasi eksternal tersebut :

- Pola komunikasi dari organisasi ke khalayak, yaitu komunikasi yang bersifat informative, yang dilakukan sedemikian rupa sehingga khalayak memiliki keterlibatan, sehingga menciptakan komunikasi yang sifatnya dua arah (two way communication). Kegiatan ini sangat penting dalam usaha memecahkan masalah dengan pihak luar.

- Pola komunikasi dari khalayak ke organisasi, yaitu feedback atau umpan balik sebagai efek dari kegiatan komunikasi yang dilakukan oleh organisasi. Komunikasi dari khalayak ke organisasi biasanya dilakukan secara langsung (direct communication) dan secara tidak langsung (indirect communication).

\section{Komunikasi Organisasi}

Komunikasi organisasi adalah pertunjukan dan penafsiran pesan di antara unit-unit komunikasi yang merupakan bagian dari suatu organisasi tertentu (Mulyana, 2001: 31-32). keputusan-keputusan yang diambil oleh anggota organisasi untuk melakukan pekerjaan secara efektif, unutk bersikap jujur kepada organisasi, untuk meraih semangat dalam organisasi, untuk melaksanakan tugas secara kreatif dan untuk menawarkan gagasan-gagasan yang inovatif bagi penyempurnaan organisasinya adalah di pengaruhi oleh komunikasi dapat diqsebut juga sebagai komunikasi organisasi (Faulos, 2001: 145).

\section{Jurnalistik}

Definisi jurnalistik adalah teknik atau keterampilan mencari, menulis, menggambarkan informasi dan berita kepada masyarakat luas (Nawiroh, 2016: 43), selain itu jurnalistik adalah segala bentuk yang membuat berita dan ulasan mengenai sampai pada kelompok pemerhati, berdasarkan definisi di atas, jurnalistik secara teknis ialah kegiatan menyiapkan, mencari, mengumpulkan, mengolah, menyajikan, dan menyebarkan berita 
melalui media berkala kepada khalayak seluas-luasnya dengan secepat-cepatnya secara serentak. Hal ini ditegaskan oleh Ronald Wolsely (dalam Mappatoto, 1993: 69-70), dimana jurnalistik ialah suatu kegiatan pengumpulan, penulisan, penafsiran, pemrosesan, dan penyebaran informasi umum, pendapat pemerhati, hiburan umum secara sistematik dan dapat dipercaya untuk diterbitkan pada surat kabar, majalah, dan disiarkan di stasiun siaran.

\section{Pers}

Dalam arti luas, pers adalah yang menyangkut kegiatan komunikasi baik yang dilakukan dengan media cetak maupun dengan media elektronik seperti radio, televisi, maupun internet. Oleh karena itu secara arti luas pers tersebut adalah sebuah media massa atau alat untuk mempublikasikan dan menyebarkan sebuah informasi secara luas (Hikmat, 2014: 17).

Selain itu secara yuridis formal, seperti yang dinyatakan dalam Pasal 1 ayat (1) UU Pokok Pers No.40/1999, pers adalah lembaga sosial dan wahana komunikasi massa yang melaksanakan kegiatan jurnalistik meliputi mencari, memperoleh, memiliki, menyimpan, mengolah, dan menyampaikan informasi baik bak dalam bentuk tulisan, suara, gambar, suara dan gambar, serta data dan grafik maupun dalam bentuk lainnya dengan menggunakan media cetak, media elektronik, dan segala jenis saluran yang tersedia.

\section{Perlindungan Hukum}

Menurut Wiener (dalam Sumadiria, 2008: 224-225) Hukum sebagai suatu sistem pengawasan perilaku (ethical control), yang diterapkan hukum adalah norma, dan norma itu merupakan produk dari suatu pusat kekuasaan yang memiliki kewenangan untuk menciptakan dan menerapkan hukum, hukum sebagai suatu sistem kontrol searah yang dilakukan oleh suatu central organ yang memili kekuasaan terhadap sistem komunikasi.

Perlindungan hukum adalah upaya melindungi kepentingan sesorang dengan cara mengalokasikan suatu kekuasaan kepadanya, untuk bertindak dalam kepentingannya tersebut. Salah satu sifat dan tujuan hukum terhadap masyarakat tersebut harus diwujudkan dalam bentuk kepastian hukum (Rahardjo, 2000: 53).

Perlindungan hukum merupakan perlindungan harkat dan martabat dan pengakuan terhadap hak asasi manusia yang dimiliki oleh subyek hukum dalam negara hukum dengan berdasarkan pada ketentuan hukum yang berlaku di negara tersebut guna mencegah terjadinya kesewenang-wenangan. Perlindungan hukum pada umumnya berbentuk suatu peraturan tertulis, sehingga sifatnya lebih mengikat dan akan mengakibatkan adanya sanksi yang harus dijatuhkan kepada pihak yang melanggarnya.

\section{Lembaga Pers Mahasiswa}

Pers mahasiswa adalah penerbitan yang dikelola dan diterbitkan oleh mahasiswa dengan dicirikan oleh idealisme kemahasiswaan (Wisnu, 2013: 5). Selain itu, pers mahasiswa adalah penerbitan dikampus yang pengelolaannya murni dilakukan oleh mahasiswa, aktivitas keredaksian sampai dengan pencarian dana dilakukan oleh mahasiswa yang masih aktif dikampus (Abrar, 1992: 7). 
Diterbitkan oleh Program Studi IImu Komunikasi

Universitas Ahmad Dahlan Yogyakarta

Menurut Majalah Prisma (dalam Wisnu, 2013: 5), salah satu ciri khas yang melekat pada pers mahasiswa adalah idealisme kemahasiswaan yang dimiliki oleh para aktivisnya. Oleh karena itu dari idealisme yang masih dipegang teguh oleh pers mahasiswa, pers mahasiswa dapat menjadi lembaga kontrol sosial disekitarnya, sekaigus sebagai alat pusat informasi dan penerbitan berita dikampus yang masih menjunjung realita dan fakta yang ada.

\section{Metode Penelitian}

Penelitian ini menggunakan metode kualitatif karena metode ini dapat mengekspolarisi secara mendalam mengenai fenomena-fenomena sosial yang tidak dapat dihitung dan bersifat deskriptif seperti persepsi, perilaku dan tindakan seseorang dalam bentuk kata-kata dan bahasa. Untuk meneliti kasus secara mendalam dan mendapatkan penyelesaian kasus yang terjadi, peneliti menggunakan pendekatan penelitian dengan metode studi kasus. Dalam mengaplikasikan studi kasus ini digunakan untuk mendeskripsikan konteks kehidupan nyata yang terlalu kompleks bagi strategi survey atau eksperimen dan peneliti hanya memiliki peluang kecil sekali atau tidak mempunyai peluang sama sekali untuk mengontrol terhadap peristiwa tersebut (Yin, 2011: 20), oleh karena itu peneliti memilih untuk menggunakan metode ini karena peneliti tidak dapat melakukan kontrol terhadap permasalahan kegiatan jurnalistik yang terjadi di LPM Suaka UIN SGD Bandung. Kasus-kasus mengenai kegiatan jurnalistik yang terjadi di LPM Suaka UIN SGD Bandung merupakan fenomena yang akan peneliti teliti agar dari studi kasus tersebut dapat disimpulkan bahwa adanya diskriminasi terhadap anggota LPM Suaka UIN SGD Bandung saat melakukan kegiatan jurnalistik.

\section{Pembahasan}

Pada tahap ini peneliti akan menguraikan hasil dari penelitian dari pola komunikasi dan pemecahan konflik yang terjadi di LPM Suaka UIN Sunan Gunung Djati Bandung.

\section{Bentuk-bentuk Komunikasi Organisasi}

a. Komunikasi internal, pola komunikasi internal dilaksanakan oleh Suaka, dimana pola komunikasi internal tersebut tarjalin antara komunikasi atasan dengan bawahan di dalam rapat pimpinan, yang berisi pimpinan umum, bendahara, sekretaris dan kepala divisi, rapat tersebut dilakukan Suaka satu bulan sekali pada minggu pertama, untuk membahas permasalahan setiap divisi yang ada.

Selanjutnya untuk permasalahan dan informasi yang menyangkut semua anggota, setelah rapat pimpinan dan mendapatkan hasil, maka akan dibahas bersama semua anggota pada rapat pleno seluruh anggota. Selanjutnya komunikasi internal pada Suaka menerapkan kesetaraan, peneliti juga melihat kondisi kegiatan yang ada pada Suaka, semua angota dan pengurus membaur menjadi satu untuk membahas suatu permasalahan.

Suaka menerapkan komunikasi internal didasari dengan kesetaraan, menurut porsi dan kebutuhan dari permasalahannya, apabila komunikasi tersebut hanya me- 
nyangkut dengan inti pimpinan maka komunikasi yang terjadi hanya lewat Rapim (Rapat Pimpinan), yang berisi enam orang, yaitu pimpinan umum, sekertaris, bendahara, kepala litbang, kepala redaksi dan kepala perusahaan, dan apabila menyangkut keseluruh anggota, maka dari rapat pimpinan, permasalahan yang diangkat di rapat tersebut, diangkat pada rapat pleno dengan anggota keseluruhan, di dalam rapat tersebut semua anggota dan pengurus diperbolehkan untuk bersuara, memberikan masukan antara bawahan dan atasan, akan tetapi semuanya sesuai dengan porsi dan kebutuhan komunikasinya masing-masing. Komunkasi internal dalam sebuah organisasi itu ditunjang dalam beberapa bentuk komunikasi antara lain, yaitu:

1) Pola Komunikasi Vertikal

Pola komunikasi vertikal yang terjadi dari atasan ke bawahan, dan dari bawahan kepada atasan berjalan dengan lancar, secara timbal balik dan terus menerus. Pimpinan memerintahkan tugas-tugas yang harus dilaksanakan oleh bawahan, dan dari tugas tersebut bawahan memberikan masukan kepada atasan, sehingga tujuan antara keduanya dapat tercapai dengan presepsi yang sama. Pada hal ini pimpinan Suaka mengadakan rapat dengan pimpinan divisi serta anggota divisi yang ada, hal ini terjadi setiap hari Senin satu minggu sekali.

Dalam pemahaman dan penerapan pola komunikasi vertikal, lembaga pers mahasiswa Suaka menggunakan pola komunikasi vertikal yaitu adanya pola komunikasi dari atasan ke bawahan, dan bawahan keatasan sehingga komunikasi tersebut terjalin dengan adanya timbal balik atau feedback antara keduanya, sehingga keduanya mempunyai tujuan yang sama dan dapat menemukan suatu kesepakatan bersama.

Hal ini diterapkan lembaga pers mahasiswa Suka, pada rapat pimpinan dan juga rapat pleno seluruh anggota yang menimbulkan komunikasi atasan dengan bawahan dan juga bawahan dengan atasan yang terlaksana setiap satu bulan sekali di minggu pertama, selain pada rapat yang terjadwal selama satu bulan sekali tersebut, para anggota juga bisa memberikan masukan kepada atasan, serta atasan memberi arahan kepada anggota pada kegiatan sharing bersama setiap harinya di sekretariat Suaka, sehingga keduanya mempunyai tujuan yang sama dan dapat menemukan suatu kesepakatan bersama.

2) Pola Komunikasi Horizontal

Pola komunikasi horizontal yang terjadi antara bawahan dengan bawahan lainnya yang memiliki kedudukan yang sama dilakukan oleh anggota Suaka, keduanya saling bertukar informasi dan juga berbagi pengalaman dari masingmasing pekerjaannya. Para anggota bawahan saling membahas permasalahanpermasalahan yang ada disetiap divisi mereka dan saling memberikan masukan antara keduanya, untuk bisa memecahkan suatu masalah itu. Hal ini dilakukan oleh para anggota pada rapat antar anggota dalam satu divisi maupun antar divisi, yang membahas permasalahan yang terjadi disetiap divisi.

Dalam pemahaman dan penerapan pola komunikasi horizontal, lembaga pers mahasiswa Suaka menggunakan pola komunikasi horizontal yaitu adanya pola komunikasi yang dijalankan dari anggota bawahan dengan anggota bawahan 
lainnya yang masih dalam kedudukan yang sama, pola komunikasi ini digunakan para anggota untuk bertukar pikiran dan juga berbagi informasi untuk pemecahan suatu masalah dimasing-masing divisi, dari pola komunikasi yang berjalan ini menghasilkan sebuah keterbukaan antar anggota dan memudahkan komunikasi anggota satu divisi dengan divisi lainnya. Suaka juga melakukan komunikasi horizontal yang sesuai dengan teori yang ada. Dari pola komunikasi yang berjalan ini menghasilkan sebuah keterbukaan antar anggota dan memudahkan komunikasi anggota satu divisi dengan divisi lainnya.

3) Pola Komunikasi Diagonal

Pola komunikasi diagonal yang terjadi antara pemimpin divisi dengan anggota bawahan dalam satu divisi maupun di luar divisi. Pemimpin divisi selalu membuat komunikasi lewat rapat divisi atau berupa bincang-bincang dalam suatu forum yang berisi antara pemimpin divisi dan para anggota divisinya, untuk membahas permasalahan-permasalahan yang timbul di dalam divisi tersebut, atau divisi satu dengan divisi lainnya.

Dalam pemahaman dan penerapan pola komunikasi diagonal, lembaga pers mahasiswa Suaka menggunakan pola komunikasi diagonal dengan menjalankan komunikasi antara kepala divisi dengan anggota divisi dalam satu divisi maupun berbeda divisi, untuk membahas permasalahan-permasalahan yang ada dalam divisi tersebut, dan menerapkan komunikasi antara kepala divisi satu dengan anggota divisi di luar divisi tersebut, berguna untuk memecahkan masalah antar divisi dan mempererat hubungan divisi satu dengan divisi lainnya, sehingga terjadi komunikasi yang bagus antar divisi, dan memudahkan pekerjaan antar divisi.

b. Komunikasi eksternal, dilaksanakan oleh Suaka, akan tetapi pola komunikasi tertentu saja yang dilakukan Suaka, komunikasi dengan pihak di luar Suaka hanya terjadi apabila Suaka membutuhkan informasi, menjalin hubungan atau bantuan dari organisasi di luar Suaka.

Komunikasi eksternal yang dilakukan Suaka, kepada organisasi eksternal di luar Suaka, yaitu berupa pencarian informasi untuk keperluan berita, dukungan organisas pers mahasiswa atau forum komunikasi pers mahasiswa untuk membantu serta bertukar pikiran dalam menghadapi masalah, serta pemecahan masalah dengan organisasi di luar Suaka akibat pemberitaan. Dalam pemahaman dan penerapan pola komunikasi eksternal, lembaga pers mahasiswa Suaka melakukan komunikasi kepada pihak eksternal, akan tetapi komunikasi tersebut berjalan secara berkelanjutan dan berkesinambungan, hanya berjalan apabila Suaka membutuhkan bantuan.

1) Pola Komunikasi dari Organisasi ke Khalayak

Pola komunikasi yang terjadi antara Suaka dengan khalayak atau organisasi di luar Suaka hanya berlangsung apabila Suaka membutuhan informasi ataupun bantuan ke organisasi di luar Suaka, pimpinan memberi tugas terhadap anggota hal ini berupa link, informasi yang dibutuhkan Suaka untuk menunjang kegiatan jurnalsitik, serta penyelesaian konflik dengan organisasi di luar Suaka, 
selebihnya Suaka tidak secara langsung dan dilakukan secara berkesinambungan melakukan komunikasi terhadap organisasi eksternal di luar Suaka.

2) Pola Komunikasi dari Khalayak ke Organisasi

Pola komunikasi yang terjadi antara organisasi di luar Suaka dengan Suaka berlangsung apabila Suaka melakukan kegiatan, contohnya secara langsung, Suaka melakukan kegiatan jurnalistik berupa penerbitan berita mengenai organisasi di luar Suaka tersebut, maka pihak organisasi di luar Suaka memberikan respon terhadap kegiatan tersebut. Hal ini terjadi di saat Suaka mengalami konflik dengan office boy (OB) dan satpam, mereka merampas majalah Suaka, setelah itu terjadilah mediasi untuk menyelesaikan masalah tersebut.

\section{Manajemen Konflik Organisasi,}

Dalam pemecahan konflik yang ada pada Suaka, para pengurus melakukan rapat internal pimpnan dahulu, membahas penyebab permasalahan tersebut bisa timbul, kemudian setelah mendapatkan penyebab dari masalah konflik tersebut diangkat dan dibahas pada rapat pleno bersama semua anggota, di dalam rapat pleno tersebut para anggota dibagi tugasnya, sesuai dengan keahliannya, untuk anggota yang dibidang redaksi membuat press release dan mempelajari konten yang dipermasalahkan, bagian litbang menghubungi pihak eksternal untuk mendukung Suaka dalam penyelesaian konflik, serta bagian pimpinan menghubungi kampus untuk menggelar mediasi, karena yang mempunyai kewenangan untuk menggelar mediasi ialah kampus, pada rapat tersebut menghasilkan kesepakatan bersama semua anggota mengenai langkah-langkah yang akan diambil untuk memanajemen konflik yang ada. Terdapat lima langkah meraih kedamaian dalam konflik, diantaranya ialah:

a. Langkah Pengenalan

Para pengurus dan anggota Suaka merespon secara tindakan dan kejanggalan yang dilakukan pihak-pihak yang berselisih dengan Suaka karena kegiatan jurnalistik berupa pemberitaan. Para anggota dan pengurus pengetahaui bahwa ada adanya konflik yang muncul akibat dari kegiatan jurnalistik yang dilakukan Suaka, dan para anggota serta pengurus melakukan respon terhadap kejadian ini, dan untuk menanggulangi tersebut.

b. Langkah Diagnosis

Para anggota dan pengurus mengembangkan masalah yang ditemukan sebelumnya pada tahap pengenalan, kemudian dilakukanlah tahap diagnosis atau analisa sementara dari temuan yang ada dilapangan, serta membahas permasalahan yang timbul. Pada tahap ini, para pengurus dan anggota melakukan tahap analisa awal mengenai penyebab utama konflik terjadi, dan melakukan beberapa usaha untuk menanggulanginya dan juga beberapa strategi untuk mengatasi konflik tersebut.

c. Langkah Menyepakati Suatu Solusi

Para pengurus dan para anggota Suaka, melakukan rapat untuk membahas suatu solusi yang tepat dalam pemecahan konflik yang ada, di dalam tahapan ini, para pengurus dan anggota melakukan rapat koordinasi, bagaimana langkah yang tepat 
Diterbitkan oleh Program Studi IImu Komunikasi

Universitas Ahmad Dahlan Yogyakarta

untuk solusi permasalahan tersebut, membahas melalui apakah forum kedua belah pihak dapat dipertemukan, dan pihak manakah yang dapat membantu masalah tersebut, serta menyusun strategi dan alat bukti yang kemungkinan besar akan di bahas saat proses pertemuan antara kedua belah pihak.

d. Langkah Pelaksanaan

Kedua belah pihak yang berselisih melakukan penerapan solusi yang telah didapat, keduanya masing-masing melaksanakan solusi yang telah disepakati kedua belah pihak lewat forum audensi. Lewat pengamatan peneliti, proses ini berjalan lancar dan kedua belah pihak menjalankan solusi yang telah disepakati, dari pihak Suaka menjalankan pengawasan terus untuk menindaklanjuti masalah ini kepada outsourcing dan pihak birokrasi karena masalah ini berawal karena pihak OB (Office Boy) dan satpam pendapatannya sangat kurang jika dibandingkan dengan pekerjaan yang dilakukannya.

e. Langkah Evaluasi

Suaka melakukan evaluasi dari semua tahapan yang telah dilakukan, serta melakukan evaluasi kegiatan jurnalistik yang dilakukan sudah memenuhi kaedah jurnalistik yang benar ataupun kode etik jurnalistik yang telah ditetapkan.

\section{E. Kesimpulan}

Berdasarkan permasalahan yang diangkat oleh peneliti, peneliti melihat komunikasi organisasi yang dilakukan pada kegiatan jurnalistik di lembaga pers mahasiswa Suaka UIN Sunan Gunung Djati Bandung, terdapat dua komunikasi organisasi yang diterapkan, yaitu:

1. Komunikasi internal, Suaka melakuakan komunikasi internal dengan menerapkan pola komunikasi vertikal, pola komunikasi horizontal dan pola komunikasi diagonal, yang didasari didasari dengan kesetaraan, menurut porsi dan kebutuhan dari permasalahannya

2. Komunikasi eksternal, Suaka melakuakan komunikasi eksternal dengan menerapkan pola komunikasi dari organisasi ke khalayak dan pola komunikasi dari khalayak ke organisasi sebagai respon timbal balik dari kegiatan organisasi. Dari kedua pola komunikasi yang terjadi, Suaka melakuakan pola komunikasi kepada organisasi eksternal di luar Suaka yaitu berupa pencarian informasi untuk keperluan berita, dukungan organisas pers mahasiswa atau forum komunikasi pers mahasiswa untuk membantu serta bertukar pikiran dalam menghadapi masalah, serta pemecahan masalah dengan organisasi di luar Suaka akibat pemberitaan. Berikut kegiatan komunikasi eksternal antara Suaka dengan organisasi eksternal di luar Suaka.

Di dalam kedua komunikasi tersebut menimbulkan pola komunikasi yang masingmasing yang terjadi, diantaranya ialah:

1. Komunikasi internal

- Pola komunikasi vertikal, pola komunikasi vertikal yang terjadi dari atasan ke bawahan, dan dari bawahan kepada atasan berjalan dengan lancar, secara timbal balik dan terus menerus. Pimpinan memerintahkan tugas-tugas 
yang harus dilaksanakan oleh bawahan, dan dari tugas tersebut bawahan memberikan masukan kepada atasan.

- Pola komunikasi horizontal, pola komunikasi horizontal yang terjadi dari anggota bawahan dengan anggota bawahan lainnya yang masih dalam kedudukan yang sama, pola komunikasi ini digunakan para anggota untuk bertukar pikiran dan juga berbagi informasi untuk pemecahan suatu masalah dimasing-masing divisi.

- Pola komunikasi diagonal, pola komunikasi diagonal yang terjadi yaitu dengan menjalankan komunikasi antara kepala divisi dengan anggota divisi dalam satu divisi maupun berbeda divisi, untuk membahas permasalahan-permasalahan yang ada dalam divisi, dan menerapkan komunikasi antara kepala divisi satu dengan anggota divisi di luar divisi.

2. Komunikasi eksternal

- Pola komunikasi dari organisasi ke khalayak yang terjadi antara Suaka dengan khalayak atau organisasi di luar Suaka hanya berlangsung apabila Suaka membutuhan informasi ataupun bantuan ke organisasi di luar Suaka, pimpinan memberi tugas terhadap anggota hal ini berupa link, informasi yang dibutuhkan Suaka untuk menunjang kegiatan jurnalsitik, serta penyelesaian konflik dengan organisasi di luar Suaka.

- Pola komunikasi dari khalayak ke organisasi yang dilakukan dimulai dari respon Suaka yang melakukan kegiatan jurnalistik berupa penerbitan berita, atau program kerja dalam bentuk kerjasama, dari hal tersebut khalayak atau organisasi eksternal merespon kegiatan yang dilakukan Suaka, dari kegiatan tersebut menimbulkan respon yang negatif dan positif. Respon positif yaitu berupa kerjasama dan respon negatif berupa masalah atau konflik mengenai.

- Berita yang diterbitkan Suaka, dari adanya respon dari pihak eksternal tersebut, pimpinan Suaka merespon balik dan membahasnya kepada anggota Suaka. Kemudian di dalam komunikasi organisasi, terdapat menajemen konflik yang terjadi, dan berikut beberapa langkah dan tahapan manajemen konflik yang diterapkan pada lembaga pers mahasiswa Suaka UIN Suanan Gunung Djati Bandung.
a. Langkah pengenalan
b. Langkah diagnosis
c. Langkah menyepakati solusi
d. Langkah penerapan solusi
e. Langkah evaluasi

\section{Daftar Pustaka}

Abrar, Ana Nadhya. 1992. Pers Mahasiswa dan Permasalahan Operasionalisasinya. Yogyakarta: Liberty. 2011. Analisis Pers: Teori dan Praktek. Yogyakarta: Cahaya Atma Pusaka.

Djamarah, Bahri Syaiful. 2004. Pola Komunikasi Orang Tua dan Anak dalam Keluarga. Jakarta: PT. Reneka Cipta 
Diterbitkan oleh Program Studi IImu Komunikasi

Universitas Ahmad Dahlan Yogyakarta

Faulos. Don. F. 2006. Komunikasi Organisasi: Strategi Meningkatkan Kinerja Perusahaan, editor Deddy Mulyana, MA, Ph.D. PT Remaja Rosdakarya. Bandung. Masmuh, Abdullah. 2008. Komunikasi Organisasi dalam Perspektif Teori dan Praktek. Malang: UMM Press.

Muhammad, Arni. 2009. Komunikasi Organisasi. Jakarta: PT. Bumi Aksara

Mulyana, Deddy. 2001. Ilmu Komunikasi: Suatu Pengantar. Bandung, Rosda

Rulliana, Poppy. 2014. Komunikasi Organisasi: Teori dan Studi Kasus. Jakarta: Rajawali Pers. Nawiroh, Vera. 2016. Komunikasi Massa. Bogor: Ghalia Indonesia

Mappatoto, Andi Baso. 1993. Siaran Pers, Suatu Kiat Penulisan. Jakarta: Gramedia Pustaka Utama.

Utomo, Wisnu. P. 2013. Pers Mahasiswa Melawan Komersialisasi Pendidikan. Jogjakarta: Indie Book Corner.

Yin, Robert. K. 2014. Studi Kasus Desain dan Metode. Jakarta: Raja Grafido Persada. 